(C) 2020. This manuscript version is made available under the CC-BY-NC-ND 4.0 license http:// creativecommons.org/licenses/by-nc-nd/4.0/. The version of record is available at https:// doi.org/10.1016/j.econmod.2020.03.021 


\title{
INVESTMENT, FIRM-SPECIFIC UNCERTAINTY, AND MARKET POWER IN SOUTH AFRICA
}

\author{
GEORGIOS CHORTAREASa,de, EMMANOUIL NOIKOKYRIS
}

and FATHIMA ROSHAN RAKEEBc

\begin{abstract}
We examine the role of firms' market power in affecting the link between firm-specific uncertainty and corporate investment decisions in a small open economy with a pronounced degree of concentration and mark-ups. Using firm-level data from South African-listed firms, we find that corporate investment of firms with low market power and market share responds positively to idiosyncratic uncertainty. A high degree of market power, however, moderates this positive relationship, allowing for delayed investment under conditions of uncertainty. The results are robust to alternative measures of firm-specific uncertainty and firms' competitive position. The finding of an association between firms' market power/market share and their capital budgeting decisions under uncertainty calls for effective competition policies.
\end{abstract}

JEL Classification: D81, E22, G31, L11

Keywords: Corporate Investment, Firm-specific uncertainty, Volatility, Market power, Market share

a Economics Group, King's Business School, King's College London, Bush House, 30 Aldwych, London, WC2 B4BG, UK. +44 (0) 207848 4164, Email: georgios.chortareas@kcl.ac.uk

b Accounting and Finance Department, Kingston University London, Kingston upon Thames, KT2 7LB, UK. Email: E.Noikokyris@kingston.ac.uk

c School of Business, University of Leicester, University Road, LE1 7RH, Leicester, UK. Email: frr4@leicester.ac.uk

d Department of Economics, National and Kapodistrian University of Athens, 1 Sophocleous Street, Athens, 10559,Greece.Email: gchortar@econ.uoa.gr

e Centre for Data Analytics for Finance and Macroeconomics, King's Business School, King's College London, Bush House, 30 Aldwych, WC2 B4BG, UK.

The authors gratefully acknowledge helpful comments and feedback from Marek Hanusch, Johannes Fedderke, Sushanta K. Mallick (the Editor), two anonymous referees, as well as participants in the World Bank Systematic Country Diagnostic workshop on Macroeconomic Volatility and Social Cohesion, Pretoria, South Africa (November 2017). 


\section{INTRODUCTION}

Extensive empirical research analyzes the effects of uncertainty on investment, producing diverse findings that can be rationalized on the basis of competing theoretical backgrounds. A strand in the literature dedicated to qualifying these results examines how the competitive environment of firms modulates the response of corporate investment to uncertainty in advanced/developed economies. The reported evidence, however, is limited, and the findings regarding both the role of market structure and the underlying investmentuncertainty relationship remain controversial. This paper assesses how firms' competitive position modulates the effect of firm-specific uncertainty on corporate investment decisions of listed firms in South Africa, an emerging small open economy with a pronounced degree of concentration and mark-ups (e.g., Aghion et al., 2008; Fedderke et al., 2018).

The ex ante role of competition in the uncertainty-investment relationship has been studied extensively in theoretical work, with ambiguous results (e.g., Caballero, 1991; Kulatilaka and Perotti, 1998). Delaying investment until uncertainty is resolved may be preferable to committing funds to irreversible projects at times of uncertainty. Inaction, however, involves the possibility of being pre-empted by competitors. The controversial nature of market competition as a moderating factor of firms' investment decisions under uncertainty is a contentious empirical question, with the relevant evidence being inconclusive. For instance, Bulan (2005) and Guiso and Parigi (1999) find that competition mitigates the negative relationship between uncertainty and investment; Henley et al. (2003) find that competition leads to a stronger positive relationship; and Shima (2016) finds that firms with higher market share exhibit a less pronounced negative uncertainty-investment relationship than other firms. Moreover, the existing empirical evidence covers only developed economies. Although market power in emerging markets has remained relatively stable since 2000, it is broadly at higher levels than in advanced economies (International Monetary Fund, 2019). 
To our knowledge, the question of how market power affects the response of corporate investment to uncertainty in emerging/developing economies has not been analysed to date. The present study, makes a step toward closing this gap, by producing empirical evidence for the emerging economy of South Africa. Earlier work considers the role of competition and uncertainty in South African industrial sector's investment decisions (e.g., Fedderke and Szalontai, 2009; Binge and Boshoff, in press), emphasizing the trade-off between scale efficiency advantages of large dominant firms and lower prices from increased competition. The most recent Systematic Country Diagnostic of the World Bank (2018) identifies low competition as one of the five key constraints faced by South Africa's economy. This motivates the focus on this small open economy and the investigation of the moderating effects of competition on the relationship between firm-specific uncertainty and investment.

South Africa is an emerging economy with high and persistent levels of market concentration and pricing power (Aghion et al., 2008; Fedderke and Szalontai, 2009; Fedderke et al., 2018). The high degree of market concentration in this country may have emerged not only as a result of scale factors, but also because of the legacy of historic privileges (e.g., Buthelezi et al., 2018). South Africa, however, is also one of the most sophisticated emerging markets globally, forms part of the BRICS group of countries, and is the leading emerging economy on the African continent in terms of potential investment destinations. In addition, the South African stock exchange ranks second globally in terms of market capitalization as a percentage of GDP, according to the World Bank, justifying the focus on listed firms and our measures of idiosyncratic uncertainty. Thus, South Africa emerges as a natural setting for testing competing theoretical predictions and qualifying results obtained from advanced economies, as well as for examining how firms' competitive position is related to their investment risk-taking in a market exhibiting signs of weak competition. 
The remainder of the paper is organized as follows. Section 2 reviews the relevant prior empirical research, Section 3 describes the data and the empirical model specifications for this study, Section 4 reports and discusses the estimation results, and Section 5 concludes the paper.

\section{UNCERTAINTY, INVESTMENT, AND COMPETITION: RELATED EVIDENCE}

According to real options theory, where investment would entail sunk costs and irreversibilities, volatility increases the value of the option to delay firms' investment decisions (Pindyck, 1993; Dixit and Pindyck, 1994). Abel (1983) shows that investment expenditure responds positively to increasing uncertainty, while Pindyck (1982) suggests that the effect of uncertainty on investment depends on the nature of the adjustment costs. The degree of market competition, however, might also affect the value of the option to delay investment. Caballero (1991), for instance, provides a theoretical model where imperfectly competitive firms are more likely to delay investment under uncertainty, because, in the presence of asymmetric adjustment costs, increasing their capital is less costly than decreasing it. Similarly, Grenadier (2002) shows that competition reduces the value of the option to delay investment by increasing fear of pre-emption. Nevertheless, there is evidence that the value of the option to wait remains significant regardless of the degree of competition (e.g., Dixit and Pindyck, 1994; Novy-Marx, 2007). In contrast, Kulatilaka and Perotti (1998) show that firms enjoying high market power are better placed to capitalize on growth options, thus increasing investment in response to higher uncertainty.

The link between uncertainty and investment, which underlies the question at hand, is one of the most extensively explored relationships in the economic and financial literature. The empirical literature yields diverse evidence, with most studies finding that higher uncertainty is associated with reduced levels of investment.1 Extensive literature, however, has explored 
the impact of different sources of uncertainty (see Koetse et al., 2009). Fedderke (2004), for instance, considers the role of sectoral and systemic uncertainty in South African investment using industry-level panel data. In this study, we focus on the firm-level impact of uncertainty on investment; therefore, we employ the idiosyncratic component of firms' volatility (Bo, 2002; Carruth et al., 2000; Leahy and Whited, 1996). Early evidence identifies idiosyncratic uncertainty, along with aggregate uncertainty, as an important determinant of corporate investment (Dixit and Pindyck, 1994).

Given that uncertainty is inherently unobservable, significant variation exists among the methods used by researchers to derive firm-specific uncertainty proxies. Empirical studies of the relationship between uncertainty and investment most commonly employ measures derived from the variability of stock returns. For instance, Baum et al. (2008, 2010a, 2010b) use the standard deviation of raw returns, while Leahy and Whited (1996) use forecasts of stock returns' volatility derived from a vector autoregressive model. Panousi and Papanikolaou (2012), Henley et al. (2003), and Bulan (2005) use the standard deviation of residual returns from the regression of firms' excess returns on aggregate stock market returns. Other studies obtain proxies of firm-specific uncertainty using changes in firms' sales (Bo, 2002; Shima, 2016), or survey data (Guiso and Parigi, 1999).

The findings of empirical studies on the relationship between firm-specific uncertainty, derived from firms' stock returns, and corporate investment are quite diverse. Some studies, using data from the US, find that higher uncertainty reduces firms' investment behavior (Baum et al. ,2008, 2010a, 2010b; Bulan, 2005; Panousi and Papanikolaou, 2012). Leahy and Whited (1996) also report a negative relationship between uncertainty and investment using firm-level data from the US; however, this relationship becomes statistically insignificant when Tobin's $Q$ is included in the model. In contrast, Henley et al. (2003), who use UK data, report a positive relationship between firm-specific uncertainty and investment. Extant research, however, has 
also identified factors that affect the sign and magnitude of this relationship, with firms' competitive environment playing a prominent role (e.g., Caballero, 1991 and Aghion et al., 2001). Other lines of research focus on the level of insider ownership (Panousi and Papanikolaou, 2012), investors' degree of risk aversion (Miao and Wang, 2007), financial frictions (Gilchrist et al., 2014), and the use of managers' compensation contracts (Glover and Levine, 2015).

Although the extant theoretical literature almost universally subscribes to the view that the degree of competition plays a prominent role in the relationship between uncertainty and investment, the attempts to analyze this role empirically are relatively limited, and the evidence produced is inconclusive. The typical finding of the limited related empirical literature, which considers only developed economies, is that competition attenuates the negative relationship between uncertainty and investment. Competition is measured either by industry concentration (Bulan, 2005; Ghosal and Loungani, 1996; Shima, 2016) or by firms' price-cost margin (Drakos and Goulas, 2006; Guiso and Parigi, 1999). Shima (2016), however, uses the firms' market share to proxy for their competitive position, and finds the opposite result. As noted above, Henley et al. (2003), on the contrary, find a positive relationship between firm-specific volatility and investment in the $\mathrm{UK}$, and this relationship tends to be more pronounced for firms in highly concentrated industries. The crux of this issue is that in order to identify the overall effect of competition on the uncertainty-investment relationship, one needs to consider the capital budgeting implications of both the investment's irreversibility and the strategic interplay among competing firms in the industry (Ghosal and Loungani, 1996).

The measurement of market structure varies in the literature, with different studies using different proxies to capture varying levels of product market competition. A number of papers, which consider the uncertainty-market power relationship, use proxies of market structure at the industry level, such as the Herfindahl-Hirschman Index (Shima, 2016), four- 
firm concentration ratios (Bulan, 2005; Ghosal and Loungani, 1996), or the number of firms within the industry (Bulan et al., 2009). Other studies account for firms' heterogeneity in terms of competitive position, using firm-level proxies of market structure. Firm-specific proxies of competitive position capture the unique circumstances of each firm, rather than the collective behavior of a group of firms, as industry-wide measures do. Such measures that feature prominently in the literature are the price-cost margin (Gaspar and Massa, 2006) and the market share (Shima, 2016). In the analysis that follows, we consider both measures of firms' competitive position, as well as two measures of firm-specific uncertainty, derived by stock returns, to ensure that the results are not driven by the proxy employed.

\section{DATA AND EMPIRICAL STRATEGY}

We examine the impact of firm-specific uncertainty on South African listed firms' capital expenditures $(C E)$, normalized by the beginning-of-year capital $\left(K_{t-1}\right)$, from 1995 to 2017. Our sample includes annual data from all listed South African non-financial firms from Datastream/Worldscope. In particular, three quarters of our sample comprises of firms in Industrials, Basic Materials and Consumer Discretionary industrial classifications, while the rest are from Consumer Staples, Technology, Telecommunications, Health Care and Energy (to categorize firms we use the FTSE/DJ Industry Classification Benchmark system -ICBunder Datastream field: LTSL1N).2 We exclude from our analysis all firms for which data for capital expenditures, cash flows, net property plant and equipment, and common shareholders' equity are not available for three consecutive years. We also exclude observations in the one percent tails of all variables. This leaves us with a total of 177 firms.

2 According to the general industry classification system -GIC- (Worldscope Code: WC06010), almost all of these firms are Industrials. Particularly, in the estimation in Table 2 column (c), out of the 2,340 observations, 2,180 belong to firms in the GIC category 1: Industrials. 
To formally characterize the role of competition in the relationship between uncertainty and investment, we augment a benchmark reduced-form investment model with a proxy for firm-level uncertainty, a proxy of firm-specific market power, and their interaction. The empirical strategy for the benchmark model follows the main characteristics of the extant empirical literature on investment to allow comparability of the results across the different strands of the empirical work. In particular, our model includes firms' lagged investment $\left(C E_{t-1} K_{K_{t-2}}\right)$, Tobin's $Q\left(Q_{t}\right)$, cash flows $\left(C F_{t} /_{K_{t-1}}\right)$, and leverage $\left(E_{t} / K_{t}\right)$, which we measure in a similar fashion to Panousi and Papanikolaou (2012) as the ratio of common equity to capital.3 That is, our baseline model covers as special cases all the main contemporary approaches to the determinants of corporate investment.

The starting point for the construction of the reduced-form investment models is the $Q$ model of investment. Hayashi's (1982) early finding that firms' optimal investment is a function of their Tobin's $Q$ prompted the extensive use of this variable in such models. The subsequent work of Fazzari et al. (1988) shifts the focus to firms' cash flows in addition to Tobin's $Q$. Cash flow appears to be a key explanatory variable in empirical investment models accounting for firms' financing constraints, as well as for future investment opportunities that are not accurately captured by Tobin's $Q$ (Gilchrist and Himmelberg, 1995). In addition, we include a measure of firms' leverage as several empirical studies on corporate investment behavior emphasize the role of corporate debt and problems associated with debt overhang (Brown and Petersen, 2009; Panousi and Papanikolaou, 2012). Finally, another popular strand in the literature considers the dynamic aspects of investment by focusing on the lagged investment variable. This allows one to capture the persistence of the investment adjustment process, and improves the fit of empirical investment models. Eberly et al. (2012), in fact, normalized by the beginning-of-year capital. 
provide empirical evidence that lagged investment is a superior predictor of firms' capital expenditures, outperforming the combined effect of firms' Tobin's $Q$ and cash flows.

As is typical in the literature, Tobin's $Q$ and the leverage variable are lagged in the empirical investment model, while we use end-of-year values for cash flows (e.g., Andrén and Jankensgård, 2015; Carpenter and Guariglia, 2008). We provide details about the construction of the variables included in the estimated models in the notes section of Table 1 . Hence, the benchmark specification of the empirical investment model takes the following form:

$$
\frac{C E_{i, t}}{K_{i, t-1}}=c_{0}+c_{1} \times \frac{C E_{i, t-1}}{K_{i, t-2}}+c_{2} \times \frac{C F_{i, t}}{K_{i, t-1}}+c_{3} \times Q_{i, t-1}+c_{4} \times \frac{E_{i, t-1}}{K_{i, t-2}}+\varepsilon_{i, t},
$$

where $i$ indexes for firm and $t$ for year.

To identify the relationship between uncertainty and investment, we augment this baseline specification with a term measuring firm-specific uncertainty. In this paper, we consider two alternative widely used proxies for this type of uncertainty. First, following Baum et al. (2008, 2010a, 2010b), we use Merton's (1980) measure of firm-specific uncertainty $\left(\lambda^{f}\right)$, which we obtain as the annual volatility of daily stock returns adjusted for working days. Second, we use the volatility of firms' idiosyncratic returns $\left(\lambda^{I V}\right)$, similarly to Bulan (2005), Henley et al. (2003), and Panousi and Papanikolaou (2012). We compute each firm's annual idiosyncratic volatility as the yearly average of its monthly idiosyncratic return variabilities. We obtain monthly idiosyncratic volatility as the within-month standard deviation of the residuals of the following excess returns model, estimated using daily data for each firm $i$ and month $\mu$ :

$$
r_{i, \tau / \mu}=\alpha_{i}+\beta_{i} \times\left(r_{m, \tau / \mu}-r_{f, \tau / \mu}\right)+\varepsilon_{i, \tau / \mu}
$$


The term $\left(r_{m, \tau / \mu}-r_{f, \tau / \mu}\right)$ stands for the market returns in excess of the risk-free rate $\left(r_{f, \tau / \mu}\right)$, which is derived from the three-month Treasury bill rate, and $r_{i, \tau / \mu}$ represents firm $i$ 's excess daily stock returns. The subscript $\tau / \mu$ denotes day $\tau$ of month $\mu$. We compute market returns as the $\log$ difference for the Datastream-calculated South African aggregate stock market index expressed in national currency. Thus, we estimate the impact of uncertainty on firms' capital expenditure using the following specification:

$$
\begin{gathered}
\frac{C E_{i, t}}{K_{i, t-1}}=c_{0}+c_{1} \times \frac{C E_{i, t-1}}{K_{i, t-2}}+c_{2} \times \frac{C F_{i, t}}{K_{i, t-1}}+c_{3} \times Q_{i, t-1}+ \\
c_{4} \times \frac{E_{i, t-1}}{K_{i, t-2}}+c_{5} \times \lambda_{i, t-1}+\varepsilon_{i, t} .
\end{gathered}
$$

To formally capture the interaction of firms' competitive position and uncertainty in their combined effect on investment decisions, we use measures of firms' market power and market share. For robustness, we employ two alternate proxies to measure each firm's competitive position. The first is a measure of firms' market power $\left(C^{M P}\right)$, which captures firms' capacity to price above marginal cost in relation to their rivals in the same industry. We define the market power of a firm at year $t$ similarly to Gaspar and Massa (2006), as the difference between its price-cost margin (i.e., operating profits over sales) and the salesweighted average price-cost margin of all South African-listed firms for the relevant industry and year that are available in Worldscope.

The second proxy is firms' market share $\left(C^{M S}\right)$, which has also been extensively used to measure firms' competitive position (e.g., Shima, 2016). Although this measure does not explicitly capture firms' pricing power, it measures their competitive position using the value 
of their sales. Our annual measure of a firm's market share is derived as the proportion of this firm's sales relative to the total sales of all South African Worldscope firms operating within the same industry for that year. To obtain more insightful interpretations of our results, we standardize the firm-specific competition variables to take values between 0 and 1 , using the following formula:

$$
C_{i}^{n}=\frac{C_{i}-\min \left(C_{i}\right)}{\max \left(C_{i}\right)-\min \left(C_{i}\right)}
$$

$\min \left(C_{i}\right)$ and $\max \left(C_{i}\right)$ stand for the minimum and maximum value of each firm's $i$ competition variable, which we denote by $C$. The value of 0 corresponds to firms with the lowest excess product market power or market share, while higher values of the competition variables suggest improvements in a firms' competitive position.

Thus, we estimate the following equation:

$$
\begin{aligned}
\frac{C E_{i, t}}{K_{i, t-1}}= & c_{0}+c_{1} \times \frac{C E_{i, t-1}}{K_{i, t-2}}+c_{2} \times \frac{C F_{i, t}}{K_{i, t-1}}+c_{3} \times Q_{i, t-1}+ \\
& c_{4} \times \frac{E_{i, t-1}}{K_{i, t-2}}+c_{5} \times \lambda_{i, t-1}+c_{6} \times C_{i, t-1}^{n}+c_{7} \times \lambda_{i, t-1} \times C_{i, t-1}^{n}+\varepsilon_{i, t},
\end{aligned}
$$

which allows the characterization of the role of competition in the uncertainty-investment relationship, as well as the identification of competition turning points above which the underlying relationship between uncertainty and investment changes sign, in a similar fashion to Ebeke, Ombga and Laajaj (2015). Particularly, the coefficient estimate $c_{7}$ shows the change in the relationship between uncertainty and investment attributable to changes in firms' market power (or market share), while $c_{5}$ captures the impact of uncertainty on the capital expenditures of firms with the lowest excess price cost margin or market share. To the extent that these two 
coefficient estimates have opposite signs, the relationship between uncertainty and investment is non-linear, and there is a competition threshold above which the direction of the relationship changes.

\section{EMPIRICAL RESULTS}

\subsection{Baseline Specification}

Table 1 reports the median values across firms of the descriptive statistics for the variables used in the empirical analysis, along with their bootstrap standard errors. The average capital expenditure and cash flows, normalized by beginning-of-the-year capital, are larger than those typically reported in studies using Worldscope firm-level data for a cross-section of countries. The corresponding statistic reported for Tobin's $Q$ appears to be comparable with that described in previous literature (e.g., Love and Zicchino, 2006; Magud and Sosa, 2015). The average values of both proxies of firm-specific uncertainty are lower than measures from the US for the period before the 2008 global financial crisis (Baum et al., 2010a; Gaspar and Massa, 2006), whereas the average value of the proxy of firms' market power is higher than the equivalent measure for the US (Datta et al., 2013; Gaspar and Massa, 2006). Both these results are consistent with the finding of Gaspar and Massa (2006) that firms with higher market power exhibit lower idiosyncratic volatility.

-Table 1 here-

To assess the robustness of our baseline specification across different estimation methods, we estimate equation (1) using pooled Ordinary Least Squares (OLS), panel fixedeffects, and the Arellano and Bond (1991) two-step difference dynamic panel GMM estimators (available in STATA by Roodman (2009)). These are the three main methods used in related 
literature to estimate empirical investment models (e.g., Carpenter and Guariglia, 2008; Eberly et al., 2012). The results, which are reported in Table 2, show that the parameter estimates for lagged investment, cash flows, Tobin's $Q$, and leverage are positive and statistically significant. The coefficient estimates are broadly comparable to those reported in previous empirical studies from other developed and transition economies (see inter alia Baum et al., 2010a, Carpenter and Guariglia, 2008, Guariglia et al., 2012 and Panousi and Papanikolaou, 2012). The positive value of the Tobin's $Q$ regressor confirms the Tobin's $Q$ theory of investment, while that of the cash flows and leverage points to the significance of financing constraints in South African firms' investment decisions.

-Table 2 here-

The GMM estimation method is typically used in this stream of literature with dynamic empirical investment models. This modeling approach emerges as the preferred strategy because it addresses problems with fixed effects and endogeneity of regressors by firstdifferencing the data and using the lagged levels of both the dependent and independent variables as instruments. First-differencing removes the unobserved individual effects that introduce bias in the lagged dependent variable estimate. Moreover, the inclusion of GMM instruments allows one to handle both the correlation of the lagged investment variable with the error term, and the possible endogeneity problems of the financial variables in the dynamic firm-level investment model. Firms' cash flows, Tobin's $Q$, and long-term debt are jointly determined with capital budgeting decisions; therefore, we introduce them as endogenous to our model.

We find that the value of the lagged investment coefficient estimate from the GMM model lies between those of the OLS and the panel-fixed effect estimates, indicating the 
capacity of this model to produce a representative estimate for this variable (Bond et al., 2001). The results of tests of overidentifying restrictions and second-order autocorrelation of the differenced residuals also suggest that the instruments used for the GMM estimation are valid. Therefore, we use the two-step difference dynamic panel GMM estimators for the remaining estimations in the next section.

\subsection{Uncertainty, investment, and competition at the firm level}

Having established a baseline specification for the determinants of investment in South Africa, we proceed to examine the link between investment and uncertainty at firm level by estimating equation (3) for both proxies of firm-specific uncertainty. We report the results in Table 3, columns $(a)$ and $(b)$, and find a positive association between firm-specific uncertainty and investment. This result, which adds to the broad corpus of literature investigating the relationship between firm-specific uncertainty and investment, suggests that firm-level uncertainty in South Africa accelerates corporate investment. The reduced form investment model does not allow for conclusive structural interpretations of this result, which is generally at odds with the findings of studies using US data.4 However, as the subsequent analysis shows, an empirical analysis of the role of each firm's competitive position in determining the magnitude of this relationship reveals empirical regularities in the role of competition, which can be rationalized by economic theory.

-Table 3 here-

4 Aghion et al. (2001), for instance, suggests that a positive relationship could be the result of firms' attempts to escape competition. Miao and Wang (2007) provide a theoretical model showing a positive relationship between idiosyncratic risk and investment in the case where an idiosyncratic and uninsurable risk is not directly linked with the returns of the investment under incomplete markets. 
To complete the model specification, we seek to identify the impact of firms' market power on the sensitivity of investment behavior to uncertainty. Columns $(c),(d),(e)$, and $(f)$ of Table 3 show results from the estimation of equation (5), in which we interact the measures of uncertainty with the measures of firms' competitive position. When we use the first measure of firms' market power, which captures firms' capacity to price above marginal cost in relation to their rivals in the same industry $\left(C^{M P}\right)$, we find a positive sign for the uncertaintyinvestment relationship for firms with low market power (when the normalized value of $C^{M P}$ takes the value of 0$)$, regardless of the measure of uncertainty used $\left(\lambda^{f}\right.$ or $\left.\lambda^{I V}\right)$. The negative and statistically significant interactive term, however, suggests that this positive relationship diminishes for firms with higher market power. For both measures of firm-specific uncertainty, we find the turning point to be rather consistent between 0.83 and 0.88 . A similar picture emerges when we use the firms' market share as an alternative measure of competitiveness $\left(C^{M S}\right)$. In particular, as we show in columns $(e)$ and $(f)$ of Table 3 , we find that the positive uncertainty-investment relationship is less pronounced for higher market share firms. Again the turning point is relatively robust to the choice of uncertainty proxy with values ranging from 0.06 to 0.10 .

Our results point to a positive association between firms' market power (or market share) and the value of the option to delay investment. Therefore, while firms with low market power (or market share) are willing to invest in the face of firm-specific uncertainty in order to exploit potential future profitable opportunities or because of high residual capital value, this does not seem to be the case for firms of higher market power (or market share) that can delay investment. This finding regarding the implications of competition for the relationship between investment and relationship is broadly in line with prior literature on advanced economies, which typically shows that imperfect competition reinforces the negative uncertaintyinvestment relationship. 


\subsection{Robusness and some further issues}

In this section, we conduct a battery of further robustness tests to scrutinize our main finding regarding the role of competition in the uncertainty-investment relationship in South Africa. First, we present in column (a) of Table 4 the results from the estimation of equation (5) with idiosyncratic volatility and firms' market power without the inclusion of time fixed-effects.5 We want to investigate the nature of the uncertainty-investment relationship as well as the role of competition in this relationship when the impact of all observed and unobserved common time-varying effects of the macroeconomy are not taken into account. The main result about the effects of competition on the uncertainty-investment relationship remains robust to the exclusion of the time dummies from our regression, and the competition turning point remains very similar to the one reported by the preferred specification with the time fixed-effects.

-Table 4 here-

Second, we assess the robustness of our empirical findings including a richer set of control variables. Particularly, to address issues with omitted variables we now include in our benchmark specification along with cash flows, Tobin's $Q$ and leverage, also variables capturing market-wide uncertainty and firms' profitability (e.g., Panousi and Papanikolaou, 2012). Particularly, we include in our empirical investment model a measure of market uncertainty (denoted by $\lambda^{M K T}$ ) which is derived in a similar fashion to Baum et al. (2008) from the Datastream-calculated South African aggregate stock market index expressed in national currency. Moreover, we also include in our empirical model firms' $R O A$ in order to capture the impact of firms' profitability.6 We report the results from this estimation in column $(b)$ of Table

\footnotetext{
5 The results of all robustness tests presented in this section hold for both measures of uncertainty and competitive position. For reasons of brevity, these results are not tabulated, but are available from the authors on request. 6 We thank an anonymous referee for suggesting these robustness tests.
} 
4, and we show again that the positive investment-uncertainty relationship decreases marginally as firms' market power increases.

Moreover, we examine the sensitivity of our results to different measures of firms' investment opportunities. In a similar fashion to Chen and Chen (2012) and Guariglia et al. (2012), we also measure firms' investment opportunities by the change in sales (denoted by $\Delta S)$. Including the sales variable in the estimation of equation (5) produces results that leave our original finding about the role of competition in the uncertainty-investment relationship essentially unchanged, as shown in column (c) of Table 4. To further address concerns regarding the measurement accuracy of firms' investment opportunities using Tobin's $Q$, we also investigate the robustness of our estimates from equation (5) by excluding Tobin's $Q$, as in Brown and Petersen (2009). The results, which are shown in column $(d)$ of Table 4, suggest the same pattern as in our original findings reported in Table 3.

\section{CONCLUSION}

We use data from listed South African firms to investigate the extent to which firms' competitive position determines their corporate investment decisions under firm-specific uncertainty in an emerging economy characterized by high market concentration and markups. We find that while firms with low market power are willing to invest in the face of firmspecific uncertainty, firms with higher market power delay investment. In particular, we show that the proxy of firms' uncertainty correlates positively with investment behavior in the benchmark empirical model, but the magnitude of this reaction is mitigated for firms with higher market power. The results of this study qualify theoretical notions identifying imperfect competition as a factor leading to a stronger negative relationship between uncertainty and investment. 
Our findings are robust across alternative measures of firm-specific uncertainty, different measures of firms' competitive position and investment opportunities, as well as different model specifications. In particular, we consider two alternative measures of uncertainty, the within-year volatility of firms' daily stock returns and the yearly average of monthly idiosyncratic return volatilities. We find that the coefficient estimates for both measures of uncertainty are positive and statistically significant. We identify each firm's competitive position within its respective industry both by its excess product market power and its market share. The results remain robust for both alternative measures of firm-level competition. Finally, the use of different measures of firms' investment opportunities (i.e., change in sales) and different set of control variables (i.e., maket-wide uncertainty and firms' $R O A$ ) yield similar results to our main findings. Competition, therefore, enhances risk-taking in the corporate investment decisions of South African listed firms.

Our finding regarding the tendency of high market power firms to exhibit monopolistic behavior which leads to delayed investment in the face of uncertainty points to the importance of competition policy for stimulating the corporate investment. From the perspective of policymakers, this result suggests that it might be beneficial to work towards incorporating the effects of product market competition on corporate risk taking behavior in their policies. The cost to the South African economy from high market concentration and mark-ups, as reported in related literature, might not only be in terms of consumer welfare but also in terms of lower capital accumulation under uncertainty. The above observations are in line with the findings and suggestions of the lattest World Bank's Systematic Country Diagnostic (2018) for South Africa, which identifies restrictions on starting businesses as an impediment to growth and emphasizes the role of competitive infrastructure for South African firms. 


\section{REFERENCES}

Abel, A.B., 1983. Optimal investment under uncertainty. American Economic Review. 73, 228-233.

Aghion, P., Harris, C., Howitt, P., Vickers, J., 2001. Competition, imitation and growth with step-by-step innovation. The Review of Economic Studies. 68, 467-492.

Aghion, P., Braun, M., Fedderke, J., 2008. Competition and productivity growth in South Africa. Economics of Transition. 16, 741-768.

Andrén, N., Jankensgård, H., 2015. Wall of cash: The investment-cash flow sensitivity when capital becomes abundant. Journal of Banking and Finance. 50, 204-213.

Arellano, M., Bond, S., 1991. Some tests of specification for panel data: Monte Carlo evidence and an application to employment equations. The Review of Economic Studies. 58, 277-297.

Baum, C.F., Caglayan, M., Talavera, O., 2008. Uncertainty determinants of firm investment. Economics Letters. 98, 282-287.

Baum, C.F., Caglayan, M., Talavera, O., 2010a. On the investment sensitivity of debt under uncertainty. Economics Letters. 106, 25-27.

Baum, C.F., Caglayan, M., Talavera, O., 2010b. On the sensitivity of firms' investment to cash flow under uncertainty. Oxford Economic Papers. 62, 286-306.

Binge, L.H., Boshoff, W.H., in press. Economic uncertainty in South Africa. Economic Modelling.

Bo, H., 2002. Idiosyncratic uncertainty and firm investment. Australian Economic Papers. 41, 1-14.

Bond, S., Hoeffler, A., Temple, J., 2001. GMM Estimation of Empirical Growth Models. Economic Papers 2001-W21, Economics Group, Nuffield College, University of Oxford.

Brown, J., Petersen, B., 2009. Why has the investment-cash flow sensitivity declined so sharply? Rising R\&D and equity market developments. Journal of Banking and Finance. 33, 971-984.

Bulan, L.T., 2005. Real options, irreversible investment and firm uncertainty: New evidence from U.S. firms. Review of Financial Economics. 14, 255-279.

Bulan, L., Mayer, C. Somerville, T., 2009. Irreversible investment, real options, and competition: Evidence from real estate development. Journal of Urban Economics. 65, 237251.

Buthelezi, T., Mtani, T. Mncube, L., 2018. The extent of market concentration in South Africa's product markets. Competition Commission South Africa, Working Paper CC2018/05. 
Caballero, R.J., 1991. On the sign of the investment-uncertainty relationship. American Economic Review. 81, 279-288.

Carpenter, R.R., Guariglia, A., 2008. Cash flow, investment, and investment opportunities: New tests using UK panel data. Journal of Banking and Finance. 32, 1894-1906.

Carruth, A., Dickerson, A., Henley, A., 2000. What do we know about investment under uncertainty? Journal of Economic Surveys. 14, 119-154.

Chen, H. (Jason), Chen, S. (Jenny), 2012. Investment-cash flow sensitivity cannot be a good measure of financial constraints: Evidence from the time series. Journal of Financial Economics. 103, 393-410.

Datta, S., Iskandar-Datta, M., Singh, V., 2013. Product Market Power, Industry Structure, and Corporate Earnings Management. Journal of Banking \& Finance. 37, 3273-3285.

Dixit, A.K., Pindyck, R.S., 1994. Investment under uncertainty. Princeton University Press, Princeton, NJ.

Drakos, K., Goulas, E., 2006. Investment and conditional uncertainty: The role of market power, irreversibility, and returns-to-scale. Economics Letters. 93, 169-175.

Ebeke, C., Ombga, L.D., Laajaj, R., 2015. Oil, governance and the (mis)allocation of talent in developing countries. Journal of Development Economics 114, 126-141.

Eberly, J., Rebelo, S., Vincent, N., 2012. What explains the lagged-investment effect? Journal of Monetary Economics. 59, 370-380.

Fazzari, S.M., Hubbard, R.G., Petersen, B.C., Blinder, A.S., Poterba, J.M., 1988. Financing Constraints and Corporate Investment. Brookings Papers on Economic Activity. 1988, 141206.

Fedderke, J., 2004. Investment in fixed capital stock: Testing for the impact of sectoral and systematic uncertainty. Oxford Bulletin of Economics and Statistics. 66, 165-187.

Fedderke, J., Szalontai, G., 2009. Industry concentration in South African manufacturing industry: Trends and consequences, 1972-96. Economic Modelling. 26, 241-250.

Fedderke, J., Obikili, N., Viegi, N., 2018. Markups and concentration in South African manufacturing sectors: An analysis with administrative data. South African Journal of Economics. 86, 120-140.

Gaspar, J., Massa, M., 2006. Idiosyncratic volatility and product market competition. The Journal of Business. 79, 3125-3152.

Ghosal, V., Loungani, P., 1996. Product Market Competition and the Impact of Price Uncertainty on Investment: Some Evidence From US Manufacturing Industries. The Journal of Industrial Economics. 44, 217-228. 
Gilchrist, S., Himmelberg, C.P., 1995. Evidence on the role of cash flow for investment. Journal of Monetary Economics. 36, 541-572.

Gilchrist, S., Sim, J.W., Zakrajšek, E., 2014. Uncertainty, Financial Frictions, and Investment Dynamics. NBER Working Paper 20038.

Glover, B., Levine, O., 2015. Uncertainty, Investment, and managerial incentives. Journal of Monetary Economics. 69, 121-137.

Grenadier, R.S., 2002. Option exercise games: An application to the equilibrium investment strategies of firms. The Review of Financial Studies. 15, 691-721.

Guariglia, A., Tsoukalas, J., Tsoukas, S., 2012. Investment, irreversibility, and financing constraints: Evidence from a panel of transition economies. Economics Letters. 117, 582584.

Guiso, 1., Parigi, G., 1999. Investment and demand uncertainty. Journal of Economics. 114, $185-227$.

Hayashi, F., 1982. Tobin's Marginal q and Average q: A Neoclassical Interpretation. Econometrica. 50, 213-224.

Henley, A., Carruth, A., Dickerson, A., 2003. Industry-wide versus firm-specific uncertainty and investment: British company panel data evidence. Economics Letters. 78, 87-92.

International Monetary Fund, 2019. World Economic Outlook, April 2019: Growth Slowdown, Precarious Recovery. International Monetary Fund.

Koetse, M.J., de Groot, H.L.F., Florax, R.J.G.M., 2009. A Meta-Analysis of the Investment-Uncertainty Relationship. Southern Economic Journal. 76, 283-306.

Kulatilaka, N., Perotti, E.C., 1998. Strategic growth options. Management Science. 44, 1021-1031.

Leahy, J.V. Whited, T.M., 1996. The effect of uncertainty on Investment: Some stylized facts. Journal of Money, Credit and Banking. 28, 64-83.

Love, I., Zicchino, L., 2006. Financial development and dynamic investment behavior: Evidence from panel VAR. The Quarterly Review of Economics and Finance. 46, 190-210.

Magud, N., Sosa, S., 2015. Investment in emerging markets we are not in Kansas anymore... Or are we. IMF Working Paper 15/77.

Merton, R.C., 1980. On estimating the expected return on the market: An exploratory investigation. Journal of Financial Economics. 8, 323-361.

Miao, J., Wang, N., 2007. Investment, consumption, and hedging under incomplete markets. Journal of Financial Economics. 86, 608-642. 
Novy-Marx, R., 2007. An Equilibrium model of investment under uncertainty. The Review of Financial Studies. 20, 1461-1502.

Panousi, V., Papanikolaou, D., 2012. Investment, idiosyncratic risk, and ownership. The Journal of Finance. 67, 1113-1148.

Pindyck, R.S., 1982. Adjustment costs, uncertainty, and the behavior of the firm, American Economic Review. 72, 415-427.

Pindyck, R.S., 1993. A note on competitive investment under uncertainty. American Economic Review. 83, 273-277.

Roodman, D., 2009. How to do xtabond2: An introduction to difference and system GMM in Stata. Stata Journal. 9, 86-136.

Shima, K., 2016. Negative uncertainty sensitivity of investment and market structure. Economics Letters. 147, 93-95.

World Bank, 2018. South Africa - Systematic country diagnostic : an incomplete transition - overcoming the legacy of exclusion in South Africa (English). Washington, D.C.: World Bank Group. http://documents.worldbank.org/curated/en/815401525706928690/SouthAfrica-Systematic-country-diagnostic-an-incomplete-transition-overcoming-the-legacyof-exclusion-in-South-Africa 


\section{TABLES AND FIGURES}

TABLE 1

SUMMARY STATISTICS

\begin{tabular}{lccccc}
\hline & Mean & St.Dev. & $1_{s t}$ Quartile & Median & 3rd Quartile \\
\hline \multirow{2}{*}{$C E_{t} / K_{t-1}$} & .421 & .298 & .171 & .288 & .516 \\
& $(.006)$ & $(.009)$ & $(.001)$ & $(.004)$ & $(.007)$ \\
$C F_{i, t} / K_{i, t-1}$ & .641 & .673 & .292 & .541 & .858 \\
& $(.008)$ & $(.036)$ & $(.010)$ & $(.017)$ & $(.019)$ \\
$Q_{i, t}$ & 1.367 & .471 & 1.049 & 1.265 & 1.543 \\
$E_{t} / K_{t}$ & $(.012)$ & $(.007)$ & $(.008)$ & $(.009)$ & $(.007)$ \\
& 2.281 & 1.480 & 1.554 & 2.253 & 3.072 \\
$\lambda_{f}$ & $(.093)$ & $(.101)$ & $(.028)$ & $(.013)$ & $(.055)$ \\
& .389 & .160 & .284 & .361 & .465 \\
$\lambda$ & $(.003)$ & $(.001)$ & $(.003)$ & $(.009)$ & $(.004)$ \\
& .392 & .144 & .274 & .350 & .463 \\
& $(.005)$ & $(.003)$ & $(.002)$ & $(.005)$ & $(.010)$ \\
$C M P$ & -.016 & .056 & -.054 & -.009 & .025 \\
& $(.001)$ & $(.002)$ & $(.001)$ & $(.001)$ & $(.001)$ \\
$C_{M S}$ & .002 & .001 & .001 & .002 & .003 \\
& $(.0002)$ & $(.000)$ & $(.0001)$ & $(.0001)$ & $(.0004)$ \\
\hline
\end{tabular}

Notes: The values reported in upright text correspond to the median values of the statistics across firms. $C E$ stands for capital expenditure (Worldscope code: WC04601). CF is obtained as the product of cash flows/sales (Worldscope code: WC08311) and net sales or revenues (Worldscope code: WC01001). $Q$ stands for Tobin's $Q$ and is the ratio of the sum of market capitalization (Worldscope code: WC08001) and total liabilities (Worldscope code: WC03351) to the sum of common equity's book value, denoted by $E$, (Worldscope code: WC03501) and total liabilities (Worldscope code: WC03351). $K_{t-1}$ is firms' beginning-of-year capital, obtained as the end-ofyear net property, plant and equipment (WC02501) minus the capital expenditure for the year. The variables $\lambda^{f}$ and $\lambda^{I V}$ measure firm-specific uncertainty, and are described in the main body of the text. $C^{M P}$ measures firms' market power following Gaspar and Massa (2006), and $C^{M S}$ is firms' market share in their respective industries. Values in parentheses are bootstrap standard errors. 
TABLE 2

BASELINE INVESTMENT MODEL

\begin{tabular}{lccc}
\hline Investment to Capital & $(a)$ & $(b)$ & $(c)$ \\
\hline \multirow{2}{*}{$C E_{i, t-1} / K_{i, t-2}$} & $.349 * * *$ & $.216^{* * *}$ & $.234 * * *$ \\
& $(8.15)$ & $(13.15)$ & $(3.84)$ \\
$C F_{i, t} / K_{i, t-1}$ & $.068^{* * *}$ & $.069 * * *$ & $.136 * * *$ \\
& $(8.98)$ & $(17.70)$ & $(2.63)$ \\
$Q_{i, t-1}$ & $.052^{* * *}$ & $.099 * * *$ & $.236 * * *$ \\
& $(4.80)$ & $(5.93)$ & $(2.65)$ \\
$E_{i, t-1} / K_{i, t-2}$ & $.002 * * *$ & $.003 * * *$ & $.003 * *$ \\
Obs. & $(3.46)$ & $(9.46)$ & $(2.54)$ \\
$R 2$ & 2,547 & 2,547 & 2,340 \\
$J$-test [p-value] & 0.62 & 0.40 & - \\
AR(2) [p-value] & - & - & {$[.56]$} \\
\hline
\end{tabular}

Notes: This table reports the results from the estimation of Equation (1) using OLS with time dummies and the two-dimensional clustered standard errors of Petersen (2009) (column (a)), panel fixed-effects with time dummies (column $(b)$ ), and two-step difference dynamic panel GMM with robust standard errors and time dummies (column $(c)$ ). The instrument list in column (c) includes the second to third lags of $C E_{t} / K_{t-1}, C F_{t} / K_{t-1}, Q_{t}$, and $E_{t} / K_{t}$. In [.] we report the p-values of the $J$ test of overidentifying restrictions for the null of suitability of the instrument set, and of the test for second-order serial correlation in the differenced disturbances of the empirical investment model. We report the $t$-statistic for each estimate in the parenteses. $* / * * * * *$ denotes significance at $90 \%, 95 \%$, and $99 \%$ confidence levels respectively. 
TABLE 3

INVESTMENT, UNCERTAINTY AND MARKET POWER

\begin{tabular}{|c|c|c|c|c|c|c|}
\hline Investment to Capital & (a) & (b) & (c) & (d) & $(e)$ & $(f)$ \\
\hline & $.260 * * *$ & $.221 * * *$ & $.255^{* * *}$ & $.227 * * *$ & $.267 * * *$ & $.226 * * *$ \\
\hline$C E_{i, t-1} / K_{i, t-2}$ & $(5.53)$ & $(4.63)$ & $(5.38)$ & $(4.12)$ & $(5.55)$ & $(5.24)$ \\
\hline & $.155 * * *$ & $.159 * * *$ & $.144 * * *$ & $.134 * * *$ & $.154 * * *$ & $.158 * * *$ \\
\hline$C F_{i, t} / K_{i, t-1}$ & $(3.71)$ & (4.04) & (3.69) & (2.96) & $(3.60)$ & $(4.69)$ \\
\hline & $.219 * *$ & $.224 * * *$ & $.233 * * *$ & $.257 * * *$ & $.238 * * *$ & $.242 * * *$ \\
\hline$Q_{i, t-1}$ & $(2.46)$ & $(2.62)$ & $(2.71)$ & $(2.73)$ & $(2.62)$ & $(2.79)$ \\
\hline$E_{i}, / K_{i}$ & $.004 * *$ & $.004 * *$ & $.004 * * *$ & $.003 * * *$ & $.004 * *$ & .004 \\
\hline$E_{i, t-1} / K_{i, t-2}$ & $(4.30)$ & $(4.60)$ & $(4.25)$ & $(3.37)$ & $(4.21)$ & $(5.34)$ \\
\hline$\lambda_{i, t-1}^{f}$ & $\begin{array}{l}.295^{* *} \\
(2.03)\end{array}$ & - & $\begin{array}{l}.518^{* *} \\
(2.26)\end{array}$ & - & $\begin{array}{l}.290 * * \\
(2.01)\end{array}$ & - \\
\hline$\lambda_{i, t-1}^{I V}$ & - & $\begin{array}{l}.227 * \\
(1.93)\end{array}$ & - & $\begin{array}{l}.424 * * \\
(1.97)\end{array}$ & - & $\begin{array}{l}.225^{*} \\
(1.91)\end{array}$ \\
\hline$C_{i, t-1}^{M P}$ & - & - & $\begin{array}{l}.387^{*} \\
(1.76)\end{array}$ & $\begin{array}{l}.372 * \\
(1.76)\end{array}$ & - & - \\
\hline$C_{i, t-1}^{M S}$ & - & - & - & & $\begin{array}{l}-.414 \\
(-0.39)\end{array}$ & $\begin{array}{l}-.024 \\
(-0.04)\end{array}$ \\
\hline$\lambda_{i, t-1}^{f} \times C_{i, t-1}^{M P}$ & - & - & $\begin{array}{c}-.586^{* *} \\
(-2.16)\end{array}$ & - & - & - \\
\hline$\lambda_{i, t-1}^{I V} \times C_{i, t-1}^{M P}$ & - & - & - & $\begin{array}{c}-.509 * * \\
(-2.10)\end{array}$ & - & - \\
\hline$\lambda_{i, t-1}^{f} \times C_{i, t-1}^{M S}$ & - & - & - & - & $\begin{array}{c}-2.744 * * * \\
(-2.75)\end{array}$ & - \\
\hline$\lambda_{i, t-1}^{I V} \times C_{i, t-1}^{M S}$ & - & - & - & - & - & $\begin{array}{c}-3.740 * * * \\
(-3.18)\end{array}$ \\
\hline $\begin{array}{l}\text { Competitiveness turning- } \\
\text { point }\end{array}$ & - & - & 0.88 & 0.83 & 0.10 & 0.06 \\
\hline Obs. & 2,241 & 2,280 & 2,163 & 2,202 & 2,212 & 2,251 \\
\hline$J$-test [p-value] & {$[0.76]$} & {$[0.91]$} & {$[0.83]$} & {$[0.62]$} & [0.69] & {$[0.81]$} \\
\hline $\mathrm{AR}(2)$ [p-value] & [0.55] & {$[0.64]$} & {$[0.65]$} & {$[0.81]$} & [0.48] & {$[0.58]$} \\
\hline
\end{tabular}

Notes: Instrument list includes the second to third lags of $C E_{t} / K_{t-1}, C F_{t} / K_{t-1}, Q_{t}, E_{t} / K_{t}, \lambda$, and $C$, as well as of the interaction of $\lambda$ with $C$ (where applicable). All specifications include time-dummies. We report the robust $t$-statistic for each estimate in the parenteses. In [.] we report the p-values of the $J$-test of overidentifying restrictions for the null of suitability of the instrument set, and of the test for second-order serial correlation in the differenced disturbances of the empirical investment model. $* / * * * * *$ denotes significance at $90 \%, 95 \%$, and $99 \%$ confidence levels respectively. 
TABLE 4

ROBUSTNESS TESTS

\begin{tabular}{|c|c|c|c|c|}
\hline $\begin{array}{l}\text { Investment to } \\
\text { Capital }\end{array}$ & (a) & (b) & (c) & (d) \\
\hline$C E_{i, t-1} / K_{i, t-2}$ & $\begin{array}{l}.224 * * * \\
(3.99)\end{array}$ & $\begin{array}{c}.223 * * * \\
(3.60)\end{array}$ & $\begin{array}{l}.216^{* * *} \\
(3.49)\end{array}$ & $\begin{array}{c}\text {.310*** } \\
(6.24)\end{array}$ \\
\hline$C F_{i, t} / K_{i, t-1}$ & $\begin{array}{c}.136 * * * \\
(3.26)\end{array}$ & $\begin{array}{l}.103 * * \\
(2.54)\end{array}$ & $\begin{array}{l}.103 * * \\
(2.30)\end{array}$ & $\begin{array}{c}.164 * * * \\
(3.02)\end{array}$ \\
\hline$Q_{i, t-1}$ & $\begin{array}{l}.281 * * \\
(2.56)\end{array}$ & $\begin{array}{l}.189 \\
(1.62)\end{array}$ & $\begin{array}{l}.177 \\
(1.43)\end{array}$ & - \\
\hline$E_{i, t-1} / K_{i, t-2}$ & $\begin{array}{c}.003^{* * *} * \\
(3.79)\end{array}$ & $\begin{array}{l}.002 * * \\
(2.53)\end{array}$ & $\begin{array}{l}.002 * * \\
(2.18)\end{array}$ & $\begin{array}{c}.001 * * * \\
(6.18)\end{array}$ \\
\hline$\Delta S_{i, t-1}$ & - & - & $\begin{array}{l}-.053 \\
(-0.80)\end{array}$ & - \\
\hline$\lambda_{i, t-1}^{I V}$ & $\begin{array}{l}.588 * * \\
(2.17)\end{array}$ & $\begin{array}{l}.306^{*} \\
(1.89)\end{array}$ & $\begin{array}{l}.284^{*} \\
(1.76)\end{array}$ & $\begin{array}{l}.635^{* *} \\
(2.32)\end{array}$ \\
\hline$C_{i, t-1}^{M P}$ & $\begin{array}{l}.523^{*} \\
(1.94)\end{array}$ & $\begin{array}{l}.247 * \\
(1.85)\end{array}$ & $\begin{array}{c}.352 * * * \\
(2.83)\end{array}$ & $\begin{array}{l}.497 * * \\
(1.99)\end{array}$ \\
\hline $\mathrm{ROA}_{i, t-1}$ & 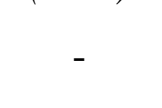 & $\begin{array}{l}.006^{*} \\
(1.69)\end{array}$ & $\begin{array}{l}.005^{*} \\
(1.75)\end{array}$ & 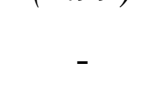 \\
\hline$\lambda_{t-1}^{M K T}$ & - & $\begin{array}{l}0.058 \\
(1.18)\end{array}$ & $\begin{array}{l}.057 \\
(1.21)\end{array}$ & - \\
\hline$\lambda_{i, t-1}^{I V} \times C_{i, t-1}^{M P}$ & $\begin{array}{c}-.678^{* *} \\
(-2.31)\end{array}$ & $\begin{array}{l}-.390 * * \\
(-2.21)\end{array}$ & $\begin{array}{c}-.396 * * * \\
(-2.59)\end{array}$ & $\begin{array}{c}-.777 * * * \\
(-2.65)\end{array}$ \\
\hline $\begin{array}{l}\text { Competitiveness } \\
\text { turning-point }\end{array}$ & 0.87 & 0.79 & 0.72 & 0.82 \\
\hline $\begin{array}{l}\text { Obs. } \\
J \text {-test [p-value] }\end{array}$ & $\begin{array}{l}2,202 \\
{[0.46]}\end{array}$ & $\begin{array}{l}2,169 \\
{[0.19]}\end{array}$ & $\begin{array}{l}2,165 \\
{[0.18]}\end{array}$ & $\begin{array}{l}2,274 \\
{[0.44]}\end{array}$ \\
\hline $\operatorname{AR}(2)$ [p-value] & {$[0.80]$} & {$[0.86]$} & {$[0.75]$} & {$[0.81]$} \\
\hline
\end{tabular}

Notes: Column (a) reports estimation results of Equation (5) without time dummies. In column $(b)$, we report the estimation results of the empirical specification in Equation (5) augmented by a measure of (lagged) market uncertainty ( $\left.\lambda_{t-1}^{M K T}\right)$ and a measure of firms' (lagged) profitability $\left(R O A_{i, t-1}\right)$. In column $(c)$, we repeat the estimation in column $(b)$, but now we also include an alternative measure of firms' investing opportunities (that is, the change in firms' sales denoted by $\left.\Delta S_{i, t-1}\right)$. In column $(d)$, we report the results from the estimation of Equation (5) without the lagged Tobin's $Q$. Instrument list includes the second to third lags of all independent variables as well as of the interaction of $\lambda^{I V}$ with $C^{M P}$. All specifications include time-dummies. We report the robust $t$-statistic for each estimate in the parenteses. In [.] we report the p-values of the $J$-test of overidentifying restrictions for the null of suitability of the instrument set, and of the test for second-order serial correlation in the differenced disturbances of the empirical investment model. $* / * * * * *$ denotes significance at $90 \%, 95 \%$, and $99 \%$ confidence levels respectively. 